\title{
Soil physical and chemical properties changes after zinc contamination
}

\section{Tatiana Bauer ${ }^{1}$, Tatiana Minkina1, David Pinskii², Inna Zamulina ${ }^{1}$, Saglara Mandzhieva ${ }^{1}$, Dina Nevidomskaya ${ }^{1}$, and Marina Burachevskaya ${ }^{1}$}

1Southern Federal University, 105, Bolshaya Sadovaya Street, 344090, Rostov-on-Don, Russian Federation

${ }^{2}$ Institute of Physicochemical and Biological Problems of Soil Science,

Russian Academy of Sciences, 2, Institutskaya Street, 142290, Pushchino, Russian Federation

Address correspondence and requests for materials to Tatiana Bauer, bauertatyana@mail.ru

\section{Abstract}

The aim of this work was to study the effect of a high rate of $\mathrm{Zn}$ on the chemical bond forms of metal in soil and on the physical properties and organic matter of Haplic Chernozem under model experiment conditions. The metal sequential extraction procedure used in this study was the classical five-step method proposed by Tessier et al. (1979). The particle size distribution was determined by the pipette method (using the pyrophosphate procedure of soil preparation) (GOST 12536-79). The microaggregate distribution was determined in the same way as the particle size distribution analysis above, except that there was no chemical dispersant (sodium pyrophosphate) applied (only mechanical agitation with water) (GOST 12536-79; Vadyunina and Korchagina, 1973). The qualitative composition of organic matter was determined using the Tyurin procedure modified by Ponomareva and Plotnikova (Vorob'eva, 2006). Contamination of Haplic Chernozem with Zn acetates at high rates of $2000 \mathrm{mg} / \mathrm{kg}$ affected the physical and chemical properties of the soil. A significant increase in the first two soil fractions least strongly bound to the soil was observed in contaminated soils. Silicates and Fe-Mn oxides made the largest contribution to the $\mathrm{Zn}$ adsorption and retention. The content of organo-mineral particles in colloidal size increased, which resulted in an increase of the clay fraction content up to $4.5 \%$ compared to the control. The qualitative composition of organic matter changed: the contents of free and sesquioxide-bound humic acids and free fulvic acids increased. Studies of soil physical properties and organic matter quality changes and chemical bond forms of $\mathrm{Zn}$ in soil are needed to better understand metal behaviors in the environment and implement repair strategies in different polluted soils.

Keywords: zinc, soil, fractional composition, organic matter, particle size distribution, structural status, aggregate content.

\section{Introduction}

Heavy metals (HMs) pollution of soil is an increasingly urgent problem all over the industrialized world. Elevated metals concentrations in soils can pose long-term risks for soil fertility and ecosystem health. Organic matter, clay minerals, as well as $\mathrm{Fe}$ and $\mathrm{Mn}$ oxides are the most important components determining the sorption of metals in soils (Vega, Covelo, and Andrade, 2006). The organic components form stable metal-organic complexes with a variety of metals, while clay minerals and oxides concentrate heavy metal ions through surface ion exchange and metal-complex surface adsorption. Soil organic matter (SOM) that plays a key role in governing metal mobility consists mainly of humic substances: humic and fulvic acids. Organic materials have large negatively charged interfaces that compete strongly with inorganic ligands to readily immobilize metal ions through the formation of stable 
complexes, thereby decreasing their phytoavailability to plants (Guo et al., 2006; Mohamed et al., 2010; Ok et al., 2011). In addition, dissolved organic matter and fulvic/ humic acids can form soluble chelates with metals, which increases metal mobility, extractability and phytoavailability under certain soil conditions (Salati, Quadri, Tambone, and Adani, 2010; Hu et al., 2016). Iron and manganese oxides present in soils are frequently nanometersized materials, which have a large surface area to volume ratio and thus are capable of binding metals. For example, T.Phuengprasop, J.Sittiwong, and F.Unob (2011) found that one gram of iron oxide-coated sludge had a capacity to adsorb $17.3,14.7$ and $42.4 \mathrm{mg}$ of $\mathrm{Cu}, \mathrm{Cd}$ and $\mathrm{Pb}$, respectively.

The environmental behavior of HMs in soils and potential risks to human health depend critically on the form in which they occur. The manner in which an element is bound to the components of the soil complex influences the mobility and, ultimately, the bioavailability and toxicity of the element to organisms (Bacon and Davidson, 2008). The availability depends on the nature of the chemical association between the metal and organic and/or inorganic soil constituents (Wang, Zhou, and Cang, 2009).

Determination of the chemical forms of trace elements in complex environmental matrices such as soils can be achieved by sequential extraction. Sequential extraction, although operationally defined, can give information about the association of heavy metals with the geochemical phases of soil. Thus, sequential extraction is widely used to reveal the distribution of heavy metals in soil fractions and to assess the mobility and toxicity of metals in soil (Guo et al., 2011).

It is known that HMs contamination also changes the quality of the soil. The HMs adsorbed by soils can affect the physical and chemical properties of the soil. Many authors have studied the effects of HM cations on the specific surface area of soils, microstructure of clay minerals, sorption of water vapors, thermodynamic state of water in clay minerals, mineralogy of the clay fraction, and distribution of HMs in aggregates of soils of different genesis (Vityazev, Kaurichev, and Rabii, 1980; Vityazev, Chizhikova, and Shevchenko, 1983; Manucharov, Kharitonova, Chernomorchenko, and Zemlyanukhin, 2001; Smagin et al., 2004; Fedotov et al., 2008). It was shown that the intensities of reflections corresponding to montmorillonites and illites on the X-ray diffraction patterns of the clay fractions from heavy loamy soddypodzolic soil and heavy loamy chernozem changed after treatment with $\mathrm{Zn}$ and $\mathrm{Cu}$ salts (Motuzova et al., 2012).

The affinity of clay minerals to HM cations is due to their high surface energy and reactivity related to the small size of particles and their morphological elements, as well as the specific properties of HM cations determined by the electron structure of their atoms. The interaction energy of HMs with clay minerals is higher than that of alkaline and alkaline-earth cations; in the general case, it changes in the following order: $\mathrm{Pb}>\mathrm{Cu}>$ $\mathrm{Ni}>\mathrm{Co}>\mathrm{Zn}>\mathrm{Mn}>\mathrm{Ba}>\mathrm{Ca}>\mathrm{Mg}>\mathrm{K}>\mathrm{Na}$ (Pinskiy and Fiala, 1985). It also depends on the acid-base properties of the exchanger; hence, the order can vary among soils and their components (Pinskiy, 1996).

It was noted that high contamination can disturb the organic matter content and quality of soils: changes in the content of the aliphatic structures inhibit the maturation of molecules of humic acids (Grishina, Koptsik, and Makarov, 1990), increase the share of fulvic acids (Karpukhin and Bushuev, 2007), and even slightly increase the organic matter content (Bezuglova and Yudina, 2006). Hence, studies on native SOM quality changes and metal-SOM interactions are needed to better understand metal behaviors in the environment and implement repair strategies in different polluted soils.

The aim of this work was to study the effect of a high rate of $\mathrm{Zn}$ on the chemical bond forms of metal in soil and on the physical properties and organic matter of Haplic Chernozem under model experimental conditions.

\section{Materials and Methods}

\section{SOIL CHARACTERISTIC}

Soil for model laboratory experiments was collected from the humus-accumulative $\mathrm{A}_{1}$ horizon of Haplic Chernozem (Clayic) (IUSS, 2015) in the Persianovskaya Steppe Specially Protected Natural Territory, Rostov Oblast, Russia. The soil has the following chemical composition: $\mathrm{C}_{\text {org }} 3.7 \%$; $\mathrm{CaCO}_{3} 0.4 \% ; \mathrm{pH}_{\mathrm{H} 2 \mathrm{O}} 7.6$; exchangeable cations $(\mathrm{mM}(+) / 100 \mathrm{~g}): \mathrm{Ca}^{2+} 31.0 ; \mathrm{Mg}^{2+} 6.0 ; \mathrm{Na}^{+} 0.06$; cation exchange capacity (CEC) $-38.0 \mathrm{mM}(+) / 100 \mathrm{~g}$. The content of the physical clay fraction (particles $<0.01 \mathrm{~mm}$ ) is $63.6 \%$; the content of the clay fraction (particles $<0.001 \mathrm{~mm}$ ) is $28.1 \%$.

The mineralogy of the clay and fine silt $(0.005-$ $0.001 \mathrm{~mm})$ fractions in the humus-accumulative horizon (0-20 cm upper layer) of Haplic Chernozem is characterized by the following phase composition of layered silicates: illite, $51-54 \%$ in the clay fraction and $51-60 \%$ in the fine silt fraction; labile silicates, $23-27 \%$ in the clay fraction and $12-27 \%$ in the fine silt fraction; kaolinite, $22-23 \%$ in the clay fraction and $22-28 \%$ in the fine silt fraction. The fine silt fraction also contains micas, amorphous silica, and crystallized iron and aluminum oxides and hydroxides (Sokolova, 1985; Kryshchenko and Kuznetsov, 2003; Nevidomskaya et al., 2016).

\section{EXPERIMENT DESIGN}

To study the effect of adsorbed $\mathrm{Zn}$ on the physical and chemical properties of Haplic Chernozem, a laboratory experiment was established under controlled condi- 
tions. The soil selected for the experiment $(1 \mathrm{~kg})$ was airdried, triturated using a pestle with a rubber head and sieved through a $1-\mathrm{mm}$ sieve. $\mathrm{Zn}$ acetate was then added separately as dry salt at a rate of $2000 \mathrm{mg} \mathrm{HM} \mathrm{kg}^{-1}$. High pollution levels are found in soils near enterprises that mine and process non-ferrous metals (Iavazzo et al., 2012; Huang, 2014; Minkina et al., 2018). It should be noted the soils such as Chernozem can retain their properties and functions even under a very high contamination level.

The soil was thoroughly mixed, wetted, and incubated for 6 months at a water content of $60 \%$ of field capacity. Experiments were performed in triplicate. Analogous procedures, although without addition of $\mathrm{Zn}$, were performed with control soil samples. After the end of incubation, an average sample was taken from each vessel for analysis. The soil was air-dried, triturated using a pest with a rubber head, and sieved through a 1 -mm sieve.

\section{SEQUENTIAL EXTRACTION}

The metal sequential extraction procedure used in this study was the classical five-step method proposed by Tessier et al. (1979), as follows:

Step 1: exchangeable fraction (F1). The solid sample $(1.0 \mathrm{~g})$ was extracted at room temperature $\left(25^{\circ} \mathrm{C}\right)$ with $8 \mathrm{~mL}$ of $1 \mathrm{~mol} \mathrm{~L}^{-1} \mathrm{MgCl}_{2}$ (pH 7.0) for $1 \mathrm{~h}$ with continuous agitation.

Step 2: carbonate-bound fraction (F2). The residue from Step 1 was extracted at room temperature $\left(25^{\circ} \mathrm{C}\right)$ with $8 \mathrm{~mL}$ of $1 \mathrm{~mol} \mathrm{~L}^{-1} \mathrm{NaOAc}$ adjusted to $\mathrm{pH} 5.0$ with HOAc, and the mixture was shaken for $5 \mathrm{~h}$.

Step 3: Fe-Mn oxide-bound fraction (F3). The residue from Step 2 was extracted with $20 \mathrm{~mL}$ of $0.04 \mathrm{~mol}$ $\mathrm{L}^{-1} \mathrm{NH}_{2} \mathrm{OH}-\mathrm{HCl}$ in $25 \%$ (volume/volume) HOAc at $96^{\circ} \mathrm{C}$ with occasional agitation for $8 \mathrm{~h}$.

Step 4: organic matter-bound fraction (F4). $3 \mathrm{~mL}$ of $0.02 \mathrm{~mol} \mathrm{~L}^{-1} \mathrm{HNO}_{3}$ and $5 \mathrm{~mL}$ of $30 \% \mathrm{H}_{2} \mathrm{O}_{2}$ adjusted to a $\mathrm{pH}$ of 2 with $\mathrm{HNO}_{3}$ was added to the residue from Step 3, and the mixture was heated to $85 \pm 2{ }^{\circ} \mathrm{C}$ for $2 \mathrm{~h}$ with occasional agitation. A second $3-\mathrm{mL}$ aliquot of $30 \% \mathrm{H}_{2} \mathrm{O}_{2}$ ( $\mathrm{pH} 2$ with $\mathrm{HNO}_{3}$ ) was then added and the sample was heated for a second time to $85 \pm 2{ }^{\circ} \mathrm{C}$ for $3 \mathrm{~h}$ with intermittent agitation. After cooling, $5 \mathrm{~mL}$ of $3.2 \mathrm{~mol} \mathrm{~L}^{-1} \mathrm{NH}_{4} \mathrm{OAc}$ in $20 \%$ (volume/volume) $\mathrm{HNO}_{3}$ was added and the sample was diluted to $20 \mathrm{~mL}$ and agitated continuously for $30 \mathrm{~min}$.

Step 5: residual fraction (F5). The residue from Step 4 was digested with an $\mathrm{HF}-\mathrm{HClO}_{4}$ mixture, and finally dissolved in $12 \mathrm{~mol} \mathrm{~L}^{-1} \mathrm{HCl}$ and diluted to $25 \mathrm{~mL}$.

All these extractions were conducted in centrifuge tubes; each step was performed in triplicate. Between each successive extraction, separation was completed using a centrifuge at $6000 \mathrm{r} \mathrm{min}^{-1}$ for $20 \mathrm{~min}$, and the supernatant was stored at $4{ }^{\circ} \mathrm{C}$ for later analysis. Laboratory equipment used in this study was washed with $0.1 \mathrm{~mol} \mathrm{~L}^{-1} \mathrm{HNO}_{3}$, rinsed with deionized water, and placed in an air-dry oven until dry. The $\mathrm{Zn}$ contents in the liquid extracts were measured by atomic absorption spectrophotometry ('KVANT 2-AT'). The total content of $\mathrm{Zn}$ in solutions was determined as the total concentrations of the metals in all fractions.

\section{METHODS OF PHYSICAL PROPERTIES AND ORGANIC MATTER DETERMINATION}

In the studied samples, the maximum hygroscopic moisture was determined according to Russian standard (GOST 28268-89); the structural state of soils was determined by the Savvinov method of dry and wet sieving; water stability was determined by the Andrianov method (Dolgov and Bahktin, 1966). The aggregate water stability coefficient was calculated from the equation:

$$
\mathrm{K}=(\mathrm{a} * \mathrm{k} 1)+(\mathrm{b} * \mathrm{k} 2)+\ldots+(\mathrm{n} * \mathrm{kn}) / \mathrm{A},
$$

where $\mathrm{a}, \mathrm{b}, \mathrm{n}$ - number of aggregates, disintegrated in one minute; k1, k2 ... kn - correction factor, which signifies aggregates water stability for each minute counting (in percentage); $\mathrm{A}$ - the total number of aggregates taken for analysis. The correction factor $\mathrm{k} 1$ is 5 for the first minute, 15 for the second minute ... 100 for the eleventh minute.

The particle size distribution (PSD) was determined by the pipette method (using the pyrophosphate procedure of soil preparation) (GOST 12536-79). In this method, carbonates, SOM, Fe, and $\mathrm{Al}$ oxides were not removed before the pipette procedure. The particles $<0.01 \mathrm{~mm}$ were united in the physical clay fraction, and the particles $>0.01 \mathrm{~mm}$ were united in the physical sand fraction. The physical clay fraction, which includes the silt fraction $(<0.001 \mathrm{~mm})$, consists of organic, organomineral and mineral particles.

The microaggregate distribution was determined as in the PSD analysis above except that there was no chemical dispersant (sodium pyrophosphate) applied (only mechanical agitation with water) (GOST 12536-79; Vadyunina and Korchagina, 1973).

The saturation degree of physical clay with clay $\left(V_{\alpha}, \%\right)$ was calculated by the Kryshchenko method (Kryshchenko et al., 2016):

$$
V_{\alpha}=100 \alpha / z,
$$

the value of $V_{\alpha}$ characterizes the relationship between the varying masses of clay $(\alpha)$ and silt $(\beta)$ present in physical clay $(z)$.

The qualitative composition of organic matter was determined using the Tyurin procedure modified by Ponomareva and Plotnikova (Vorobeva, 2006), which involved the separation of organic matter into humic acids (HAs), fulvic acids (FAs), and nonhydrolyzable 
residue (humin) followed by the fractionation of HAs and FAs depending on their bonds with the mineral soil component.

\section{STATISTICAL DATA ANALYSES}

All laboratory tests were performed in triplicate. The experimental data (means and standard deviations) were statistically treated using STATISTICA 10.0. Results were considered statistically significant at $\mathrm{p} \leq 0.05$.

\section{Results and Discussion}

As previously indicated, a sequential chemical extraction was carried out in order to identify the distribution of the metal in the different geochemical soil fractions. Table 1 shows the contents of $\mathrm{Zn}$ associated with the fractions of each soil. The relative amounts of $\mathrm{Zn}$ expressed as a percent of the cumulative total extracted are given in Fig. 1. In the uncontaminated soil most of the $\mathrm{Zn}$ is in the residual fraction ( $48 \%$ of the sum of all fractions). These values reflect the regional trace-element specifics of the composition of soils in Rostov Oblast and the mineralogy of the soil-forming rocks. Yellow brown loess-like loams and clays in Pre-Caucasian plains inherited stable minerals from the parental rocks enriched in trace elements. Ions released from the rocks in the course of their weathering and the origin of soils are partly strongly bound in the structures of clay min- erals (Minkina et al., 2016; Motuzova and Bezuglova, 2007). Organic matter also significantly contributes to the strong fixation of $\mathrm{Zn}$ : it constitutes $32 \%$ of the total metal content (Fig. 1). The relative content of $\mathrm{Zn}$ in the first two fractions, which are least strongly bound to the soil, is $3 \%$, including $1 \%$ of the most mobile exchangeable forms. The low mobility and dominance of $\mathrm{Zn}$ in the residual fraction confirm the absence of significant amounts of anthropogenic metal in the original soil. In the uncontaminated Haplic Chernozem, the following distribution of $\mathrm{Zn}$ among the compounds forms is revealed: residual fraction $>$ organic matter-bound fraction $>$ Fe-Mn oxide-bound fraction $>$ carbonate-bound fraction $>$ exchangeable fraction.

Addition of metal to the soil at a rate of $2000 \mathrm{mg} \mathrm{kg}^{-1}$, the absolute concentrations of all compounds of the metals in the soil samples increase (Table 1). The relative content of metal in the exchangeable and specifically adsorbed (carbonate-bound) fractions increases: $2 \%$ and $4 \%$ respectively (Fig. 1). A significant role of carbonates in bonding $\mathrm{Zn}$ was previously mentioned (Adriano, 2001; Minkina et al., 2016). The affinity of metal ions to carbonates is controlled by their low solubility. Heavy metals can co-precipitate with carbonates by being incorporated into their structures or can be adsorbed in Fe-Mn hydroxides that are precipitated on the surface of carbonates (Santillan-Medrano and Jurinak, 1975).

$\mathrm{Fe}-\mathrm{Mn}$ oxides play a dominant role in $\mathrm{Zn}$ accumulation. The $\mathrm{Zn}$ amount in the fraction bound to $\mathrm{Fe}-\mathrm{Mn}$

Table 1. Fractional composition of $\mathrm{Zn}$ in Haplic Chernozem under model experimental conditions, $\mathrm{mg} \mathrm{kg}^{-1}(\mathrm{n}=3)$

\begin{tabular}{|c|c|c|c|c|c|c|}
\hline \multirow[b]{2}{*}{ Soil } & \multicolumn{5}{|c|}{ Fraction } & \multirow[b]{2}{*}{$\begin{array}{l}\text { Sum of } \\
\text { fractions }\end{array}$} \\
\hline & Exchangeable & $\begin{array}{l}\text { Bound to } \\
\text { carbonates }\end{array}$ & $\begin{array}{c}\text { Bound to } \\
\text { Fe-Mn oxides }\end{array}$ & $\begin{array}{c}\text { Bound to } \\
\text { organic } \\
\text { matter }\end{array}$ & Residual & \\
\hline $\begin{array}{l}\text { Uncontaminated soil } \\
\text { (control) }\end{array}$ & $0.6 \pm 0.1$ & $1.8 \pm 0.3$ & $14.2 \pm 2.3$ & $27.5 \pm 3.4$ & $41.0 \pm 6.5$ & $85.1 \pm 12.3$ \\
\hline $\begin{array}{l}\text { Artificially contaminated } \\
\text { soil }\end{array}$ & $64.8 \pm 8.7$ & $119 \pm 13$ & $670 \pm 17$ & $321 \pm 15$ & $899 \pm 22$ & $2074 \pm 64$ \\
\hline
\end{tabular}

control

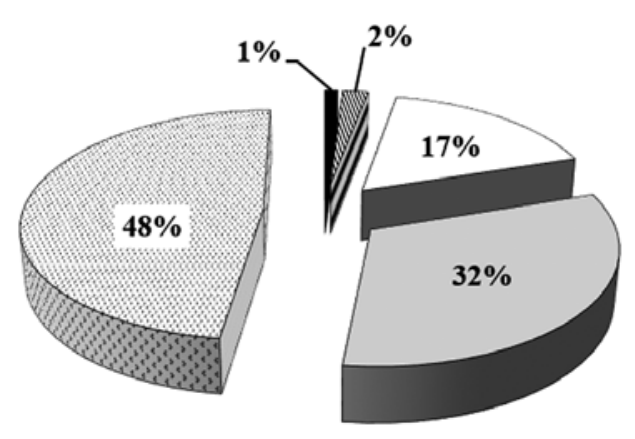

$2000 \mathrm{mg} \mathrm{kg}^{-1}$

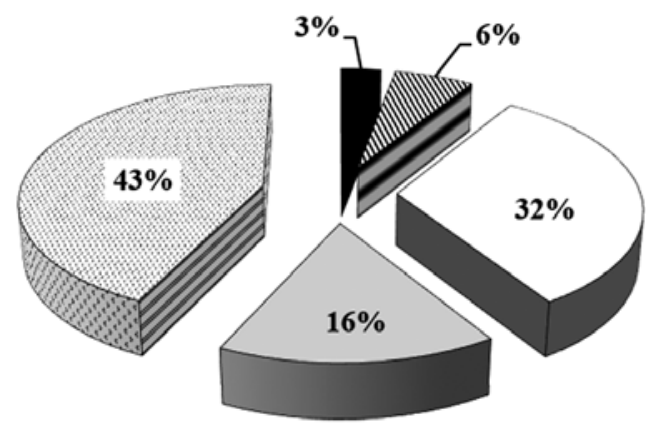

Exchangeable

\author{
$\mathbb{8}$ Bound to \\ carbonates \\ $\square$ Bound to Fe-Mn \\ oxides
}
$\square$ Bound to organic matter

Residual

Fig. 1. Fractional distribution of $\mathrm{Zn}$ in Haplic Chernozem, \% of the sum of fractions. 
oxides and hydroxides is the greatest as compared to the residual fraction increased by $25 \%$ (Fig. 1). In agreement with these results, other authors have also reported the high affinity of $\mathrm{Zn}$ for Fe oxides (Mahanta and Bhattacharyya, 2011; Yin et al., 2016; Ghayoraneh and Qishlaqi, 2017). This may be due to the stability constants of Zn oxides being high enough to be concentrated in this fraction (Ramos, Hernandez, and Gonzalez, 1994). Kabala and Singh (2001) concluded that $\mathrm{Zn}$ sorption by Fe oxides is probably the most important mechanism that controls the behavior of this element in the soils. The similarity in the effective ionic radii of $\mathrm{Zn}^{2+}, \mathrm{Fe}^{2+}, \mathrm{Fe}^{3+}$, $\mathrm{Mg}^{2+}$, and $\mathrm{Al}^{3+}$ allows its incorporation in a large number of soil minerals (Manceau et al., 2004).

In the case of soil contamination with $\mathrm{Zn}$ in the dose of $2000 \mathrm{mg} \mathrm{kg}^{-1}$, a share of the organic fraction is decreased by $16 \%$. $\mathrm{Zn}$ is capable of forming stabile complexes to a lesser extent. The organic matter plays a significant role in $\mathrm{Zn}$ immobilization in view of forming the unstable outer sphere and intrasphere complex compounds capable of transfering into the other forms of compounds (Kabata-Pendias, 2010; Rodríguez-Oroz et al., 2012).

Metal input to soil in the dose of $2000 \mathrm{mg} \mathrm{kg}^{-1}$ reveals a decrease in the share of the firmly bound residual fraction in the total content of the metal extracted from soil (Fig. 1). This serves as evidence that this metal is weakly involved in the structure of the most stable soil components. Such a peculiarity in distribution of $\mathrm{Zn}$ fractions can be used as a diagnostic criterion for natural or anthropogenic contamination of soils and the level of their contamination (Minkina et al., 2015).

The significant increase of $\mathrm{Zn}$ content in the first two fractions, which are least strongly bound to the soil, reflected the changes of soil properties.

According to the Kachinskii classification, PSD in Haplic Chernozem corresponds to the variety of light silty loess-like clays (Table 2). The content of physical clay in the control samples is $63.6 \%$. The silt fractions are predominant: the content of medium and fine silt is $35.5 \%$. The content of the clay fraction is $28.1 \%$. The saturation degree of physical clay with clay $\left(V_{\infty} \%\right)$ is $44.2 \%$.

The contamination of the studied soil with $\mathrm{Zn}$ is accompanied by changes in PSD due to the reliable increase in the content of the clay fraction compared to the control to $4.5 \%$. The content of physical clay increases respectively. The clay fraction, along with the silt fraction, becomes predominant, which allows classifying the contaminated soil samples as light clayey-silty clays. Soil samples under $\mathrm{Zn}$ contamination are characterized by an increase of the saturation of physical clay (soil particle $<0.01 \mathrm{~mm}$ ) with clay (soil particle $<0.001 \mathrm{~mm}$ ) up to $48.4 \%$ (Table 2).

Analysis of the microaggregate size composition of the studied soil (Table 3 ) shows that the content of coarser aggregates $(1-0.25 \mathrm{~mm})$ increases and the con- tent of finer $(0.05-0.001 \mathrm{~mm})$ aggregates decreases after the addition of $\mathrm{Zn}$.

The transformations of microaggregate composition are interrelated to the structural parameters of soil. High concentrations of $\mathrm{Zn}$ affect the structure of Haplic Chernozem. We observed a significant decrease in the coefficient of water stability in the control from 3 to 1.4 in the contaminated treatments (Table 4).

The aggregate status (estimated from total agronomically valuable aggregates) changes from excellent to good. Kachinskii (1958) studied the structure of soil and noted that the aggregate water stability coefficient is related to the coagulating effect of organic colloids coagulated by $\mathrm{Ca}^{2+}$ and $\mathrm{Fe}^{2+}$ ions. Some authors (Dobrovol'skii, 2004; Gülser, Minkina, Sushkova, and Kizılkaya, 2017) noted the important role of HAs in the binding of mineral particles with the formation of microaggregates. The interaction of HMs with HAs fixes them in organic films formed on the surface of aggregates.

The adsorption of $\mathrm{Zn}^{2+}$ ions by the soil exchange complex largely follows the mechanism of ion exchange (Ponizovskii, Studenikina, and Mironenko, 1999; Ponizovskii and Mironenko, 2001; Strawn and Baker, 2008; Minkina et al., 2014). The substitution of HM cations for $\mathrm{Ca}^{2+}$ and $\mathrm{Fe}^{2+}$ ions can significantly affect the water stability of the corresponding aggregates.

An increase in the specific surface area of soil and fine fractions under the treatment of soils with $\mathrm{Cu}$ and Zn salts was shown by Motuzova et al. (2012). The author explained this fact by the formation of Me-organic complexes with HM cations and the partial decomposition of mineral-organic compounds, which play an important role in structure formation. The highest effect was observed for the clay fraction of chernozem at the interaction with $\mathrm{Cu}^{2+}$ and $\mathrm{Zn}^{2+}$ ions: the specific surface area determined by nitrogen adsorption increased by $69 \%$ compared to the initial value.

The changes in the amphiphilic properties of HMcontaminated soils are of a different nature. They can be related to changes in the relative content, composition, and properties of organic and organomineral soil components (Motuzova et al., 2012). It is shown that the formation of organomineral complexes significantly affects the hydrophilic-hydrophobic properties of soils (Perelomov, Pinskiy, and Violante, 2011). The most probable mechanisms of the HM effect on the physical properties of soil can be the changes in the occurrence forms of HMs and organic matter in soils, including the formation of relatively stable complexes with organic components (Grishina, Makarov, and Baranova, 1988; Minkina, Motusova, and Nazarenko, 2006). Therefore, some organic substances acting as structuring agents are removed from the solid phase, and aggregates are disintegrated into finer units. The formation of hardly soluble HM precipitates, e.g., lead humates, gives the same effect (Manceau, Marcus, and Tamura, 
Table 2. Effect of high concentration of $\mathrm{Zn}$ on the particle-size fraction of Haplic Chernozem under model experimental conditions, \%

\begin{tabular}{|c|c|c|c|c|c|c|c|c|}
\hline \multirow[b]{2}{*}{ Soil } & \multicolumn{7}{|c|}{ The particle-size fraction content } & \multirow{2}{*}{$\begin{array}{c}\text { The saturation } \\
\text { degree of } \\
\text { physical clay } \\
\text { with clay, }\left(V_{a}\right)\end{array}$} \\
\hline & $\begin{array}{c}\text { Fine } \\
\text { sand } 0.25- \\
0.05 \mathrm{~mm}\end{array}$ & $\begin{array}{l}\text { Coarse } \\
\text { silt } 0.05- \\
0.01 \mathrm{~mm}\end{array}$ & $\begin{array}{l}\text { Medium } \\
\text { silt } 0.01- \\
0.005 \mathrm{~mm}\end{array}$ & $\begin{array}{l}\text { Fine } \\
\text { silt } 0.005- \\
0.001 \mathrm{~mm}\end{array}$ & $\begin{array}{c}\text { Clay } \\
<0.001 \mathrm{~mm}\end{array}$ & $\begin{array}{c}\text { Physical } \\
\text { sand } \\
>0.01 \mathrm{~mm}\end{array}$ & $\begin{array}{c}\text { Physical } \\
\text { clay } \\
<0.01 \mathrm{~mm}\end{array}$ & \\
\hline Uncontaminated soil & $3.7 \pm 0.1$ & $32.7 \pm 2.2$ & $11.0 \pm 0.8$ & $24.5 \pm 1.1$ & $28.1 \pm 1.6$ & $36.4 \pm 2.3$ & $63.6 \pm 3.5$ & $44.2 \pm 0.2$ \\
\hline $\begin{array}{l}\text { Artificially } \\
\text { contaminated soil }\end{array}$ & $1.3 \pm 0.2$ & $31.3 \pm 1.8$ & $10.4 \pm 0.7$ & $24.4 \pm 1.3$ & $32.6 \pm 2.2$ & $32.6 \pm 2.0$ & $67.4 \pm 4.2$ & $48.4 \pm 0.2$ \\
\hline
\end{tabular}

Table 3. Effect of high concentration of $\mathrm{Zn}$ on the microaggregate composition of Haplic Chernozem under model experimental conditions, \%

\begin{tabular}{l|c|c|c|c|c|c|c|c}
\hline \multicolumn{1}{c|}{ Soil } & $\mathbf{1 - 0 . 2 5}$ & $\mathbf{0 . 2 5}-\mathbf{0 . 0 5}$ & $\mathbf{0 . 0 5 - 0 . 0 1}$ & $\mathbf{0 . 0 1 - 0 . 0 0 5}$ & $\mathbf{0 . 0 0 5 - 0 . 0 0 1}$ & $<\mathbf{0 . 0 0 1}$ & $>\mathbf{0 . 0 1}$ & $<\mathbf{0 . 0 1}$ \\
\hline Uncontaminated soil & $41.3 \pm 2.8$ & $20.4 \pm 1.4$ & $26.2 \pm 1.8$ & $5.6 \pm 0.3$ & $6.4 \pm 0.9$ & $1.2 \pm 0.1$ & $86.8 \pm 6.0$ & $13.2 \pm 1.3$ \\
\hline $\begin{array}{l}\text { Artificially } \\
\text { contaminated soil }\end{array}$ & $43.9 \pm 3.7$ & $20.8 \pm 1.2$ & $24.6 \pm 1.2$ & $4.6 \pm 0.2$ & $4.4 \pm 0.6$ & $1.6 \pm 0.2$ & $89.3 \pm 6.1$ & $10.7 \pm 0.9$ \\
\hline
\end{tabular}

Table 4. Effect of high concentration of $\mathrm{Zn}$ on the structural status of Haplic Chernozem under model experimental conditions

\begin{tabular}{|c|c|c|c|c|c|c|c|}
\hline \multirow{2}{*}{ Soil } & \multicolumn{2}{|c|}{$\begin{array}{l}\text { The structural state } \\
\text { coefficient }\end{array}$} & \multicolumn{2}{|c|}{$\begin{array}{l}\text { The aggregate content } \\
\quad(0.25-10.0 \mathrm{~mm}), \%\end{array}$} & \multicolumn{2}{|c|}{$\begin{array}{l}\text { The agroecological } \\
\text { estimation of the structural } \\
\text { state (Dolgov, Bahktin 1966) }\end{array}$} & \multirow{2}{*}{$\begin{array}{l}\text { The water } \\
\text { stability } \\
\text { coefficient, } \%\end{array}$} \\
\hline & $\begin{array}{l}\text { dry sieving } \\
\text { method }\end{array}$ & $\begin{array}{l}\text { wet sieving } \\
\text { method }\end{array}$ & $\begin{array}{l}\text { dry sieving } \\
\text { method }\end{array}$ & $\begin{array}{l}\text { wet sieving } \\
\text { method }\end{array}$ & $\begin{array}{l}\text { dry sieving } \\
\text { method }\end{array}$ & $\begin{array}{l}\text { wet sieving } \\
\text { method }\end{array}$ & \\
\hline Uncontaminated soil & 2.0 & 3.0 & 66.5 & 75.5 & good & excellent & 100.0 \\
\hline $\begin{array}{l}\text { Artificially } \\
\text { contaminated soil }\end{array}$ & 1.9 & 1.4 & 64.9 & 60.5 & good & good & 77.4 \\
\hline
\end{tabular}

Table 5. Effect of high concentration of $\mathrm{Zn}$ on the fractional and group composition of organic matter in Haplic Chernozem, \% of $\mathrm{C}_{\text {tot }}$ in the soil

\begin{tabular}{|c|c|c|c|c|c|c|c|c|c|c|c|c|c|}
\hline \multirow{2}{*}{ Soil } & \multirow{2}{*}{$\begin{array}{c}\mathrm{C}_{\text {tot, }} \\
\%\end{array}$} & \multicolumn{3}{|c|}{$\begin{array}{l}\text { The humic acids } \\
\text { content (HAs) }\end{array}$} & \multirow{2}{*}{$\sum$ HAs } & \multicolumn{4}{|c|}{ The fulvic acids content (FAs) } & \multirow{2}{*}{$\sum$ FAs } & \multirow{2}{*}{$\begin{array}{l}\text { HAs + } \\
\text { FAs }\end{array}$} & \multirow{2}{*}{$\frac{\text { HAs }}{\text { FAs }}$} & \multirow{2}{*}{$\begin{array}{l}\text { The } \\
\text { humin } \\
\text { content }\end{array}$} \\
\hline & & 1 & 2 & 3 & & $1 a$ & 1 & 2 & 3 & & & & \\
\hline Uncontaminated soil & 3.7 & 1.4 & 21.3 & 5.9 & 28.6 & 1.6 & 1.3 & 7.8 & 4.6 & 15.3 & 43.9 & 1.9 & 56.1 \\
\hline $\begin{array}{l}\text { Artificially } \\
\text { contaminated soil }\end{array}$ & 3.8 & 2.5 & 22.0 & 6.7 & 31.2 & 3.1 & 1.7 & 8.5 & 5.9 & 19.2 & 50.4 & 1.6 & 49.6 \\
\hline
\end{tabular}

2002; Scheinost, Kretzchmar, and Pfister, 2002). Another mechanism can include the experimentally proved fragmentation of HAs during interaction with HM cations (Motuzova and Makarychev, 2014).

The results of studying the fractional and group composition of organic matter from the uncontaminated Haplic Chernozem (Table 5) agree with the data of earlier studies of regional Chernozems (Bezuglova, Zvyagintzeva, and Goryainova, 1996). In the upper horizon of virgin Haplic Chernozem, the coefficient of humification is 1.9, which characterizes the fulvate-humate type of organic matter. In the organic matter composition, HAs presumably bound to $\mathrm{Ca}$ (HA-2) prevail over FAs. Their content in the upper horizons of Haplic Chernozem is $21.3 \%$. The contents of free and sesquioxide-bound HAs (HA-1) and free FAs (FA-1a) in the control soil are low:
1.4 and $1.6 \%$, respectively (Table 5), which agrees with literature data (Bezuglova and Yudina, 2006).

The content of free HAs (HA-1) and FAs (FA-1a) increased after $\mathrm{Zn}$ application to the soil (Table 5). The contamination of Haplic Chernozem with $\mathrm{Zn}$ also increases the content of mobile HAs bound to sesquioxides (HA-3). These fractions are more mobile and responsive to changes in ecological conditions. The $\mathrm{C}_{\mathrm{HA}} / \mathrm{C}_{\mathrm{FA}}$ ratio in soils contaminated with $\mathrm{Zn}$ decreased from 1.9 to 1.6.

The qualitative composition of organic matter in contaminated soil is largely determined by adsorbed $\mathrm{Zn}$ added in the form of soluble salt. Adsorbed HM cations partially interact with SOM (Kabata-Pendias and Kabata, 1985; Onyatta and Huang, 1999; Gray, McLaren, Robert, and Condron, 2000), including in the studied soil (Minkina et al., 2016). 
Metals coming into the soil are mainly concentrated in fine silt $(0.005-0.001 \mathrm{~mm})$ and clay $(<0.001 \mathrm{~mm})$ fractions (Trofimenko and Kizyakov, 1976; Titova et al., 1996a; Titova, Travnikova, and Shaymukhametov, 1996b; Pinsky and Minkina, 2013). It is known that particle-size fractions significantly vary in properties of bound organic matter and, hence, affinity for HMs. The clay fraction includes stable adsorption complexes of the youngest humic substances (predominantly of fulvate nature) with clay minerals and iron and aluminum oxides. In the fine silt fraction, SOM consists of humic substances in the form of HAs unbound by strong chemical bonds to clay minerals. It is found (Motuzova et al., 2012) that $\mathrm{Zn}$ is mainly concentrated in the clay fraction of Haplic Chernozem. So, the content of $\mathrm{Zn}$ is $82 \mathrm{mg} \mathrm{kg}^{-1}$ in the silt fraction and $162 \mathrm{mg} \mathrm{kg}^{-1}$ in the clay fraction. Thus, the adsorbing capacity of fine particle-size fractions for HM cations is variable. The capacity of HMs to accumulate in different particle size fractions is related to their density (Titova, Travnikova, and Shaymukhametov, 1996b) and properties of their organomineral matrix (Motuzova et al., 2012).

\section{Conclusions}

Based upon a model experiment it has been established that the main $\mathrm{Zn}$ share was predominantly concentrated in the crystalline primary and secondary minerals in uncontaminated soil. In contaminated soil the metal was found in the residual fraction as well as in the fraction bounded to Fe-Mn oxides.

Under model experiment conditions the contamination of Haplic Chernozem with $\mathrm{Zn}$ was followed by changes in particle size distribution due to the increase of the organo-mineral particles content in colloidal size in the clay fraction compared to the control by $4.5 \%$. Consequently, the degree of physical clay saturation with clay increased from 44.2 to 48.4 under contamination.

The high concentrations of metal salt affected the structural state of Haplic Chernozem: the coefficient of water stability decreased and the aggregate status (estimated from total agronomically valuable aggregates) changed from excellent to good.

The addition of $\mathrm{Zn}$ to the soil affected the quantitative composition of organic matter. The contents of mobile fractions (free and sesquioxide-bound HAs (HA-1) and free FAs (FA-1a)) increased. Contamination with $\mathrm{Zn}$ caused the aliphatization of organic matter, which decreased the CHA/CFA ratio from 1.9 to 1.6.

\section{References}

Adriano, D.C. 2001. Trace Elements in Terrestrial Environments Springer-Verlag, New York-Berlin-Heidelberg.

Bacon, J.R. and Davidson, C. M. 2008. Is there a future for sequential chemical extraction? Analyst 133(1):25-46. https://doi.org/10.1039/B711896A
Bezuglova, O. S. and Yudina, N. V. 2006. Interrelationship between the physical properties and the humus content of chernozems in the south of European Russia. Eurasian Soil Science 39(2):187-194. https://doi.org/10.1134/ S1064229306020098

Bezuglova, O.S., Zvyagintzeva, Z. V., and Goryainova, N. V. 1996. Humus losses in soils of the Rostov province. Eurasian Soil Science 28(4):40-53.

Dobrovol'skii, V. V. 2004. The role of humic acids in the formation of migrational fluxes of heavy metals. Eurasian Soil Science 37(1):24-30.

Dolgov, S. I. and Bahktin, P. U. 1966. Agrophysical methods of soil examination. Kolos, Moscow.

Fedotov, G. N., Omel'Yanyuk, G. G., Bystrova, O. N., Martynkina, E. A., Gulevskaya, V. V., and Nikulina, M. V. 2008. Heavy-metal distribution in various types of soil aggregates. Doklady Chemistry 420(1):125-128. https://doi. org/10.1134/S0012500808050042

Ghayoraneh, M. and Qishlaqi, A. 2017. Concentration, distribution and speciation of toxic metals in soils along a transect around a $\mathrm{Zn} / \mathrm{Pb}$ smelter in the northwest of Iran. Journal of Geochemical Exploration 180:1-14. https://doi. org/10.1016/j.gexplo.2017.05.007

GOST 12536-79. 1979. Soils. Methods of laboratory particlesize and microaggregate-size distributions.

GOST 28268-89. 2006. Soils. Methods for determination of moisture, maximum hygroscopic moisture and moisture of steady plant fading.

Gray, C. W., McLaren, R. G, Robert, A. H. C., and Condron, L. M. 2000. Fractionation of soil cadmium from some New Zealand soils. Communications in Soil Science and Plant Analysis 31:1261-1273.

Grishina, L. A., Koptsik, G. N., and Makarov, M. I. 1990. Transformatsiya organicheskogo veshchestva pochv [Transformation of Soil Organic Matter]. Moscow State University, Moscow.

Grishina, L. A., Makarov, M. I., and Baranova, T. A. 1988. Humic acids of Sod-Podzolic soils from background and polluted forest biogeocoenoses. Soviet Soil Science 20(4):58-67.

Gülser, C., Minkina, T. M., Sushkova, S. N., and Kızılkaya, R. 2017. Changes of soil hydraulic properties during the decomposition of organic waste in a coarse textured soil. Journal of Geochemical Exploration 174:66-69. https:// doi.org/10.1016/j.gexplo.2016.05.014

Guo, G., Yuan, T., Wang, W., Li, D., and Wang, J. 2011. Effect of aging on bioavailability of copper on the fluvo aquic soil. International Journal of Environmental Science and Technology 8:715-722. https://doi.org/10.1007/BF03326256

Guo, X. Y., Zhang, S. Z., Shan, X. Q., Luo, L., Pei, Z. G., Zhu, Y. G., Liu, T., Xie, Y. N., and Gault, A. 2006. Characterization of $\mathrm{Pb}, \mathrm{Cu}$, and $\mathrm{Cd}$ adsorption on particulate organic matter in soil. Environmental Toxicology and Chemistry 25:23662373. https://doi.org/10.1897/05-636R. 1

Hu, S. H., Lu, C., Zhang, C. J., Zhang, Y. J., Yao, H. R., and Wu Y. G. 2016. Effects of fresh and degraded dissolved organic matter derived from maize straw on copper sorption onto farmland loess. Journal of Soils and Sediments 16:327-338. https://doi.org/10.1007/s11368-015-1226-z

Huang, S. H. 2014. Fractional distribution and risk assessment of heavy metal contaminated soil in vicinity of a lead/zinc mine. Transactions of Nonferrous Metals Society of China 24:3324-3331. https://doi.org/10.1016/S10036326(14)63473-7

lavazzo, P., Adamo, P., Boni, M., Hillier, S., and Zampella, M. 2012. Mineralogy and chemical forms of lead and zinc in abandoned mine wastes and soils: An example from Morocco. Journal of Geochemical Exploration 113:56-67. https://doi.org/10.1016/j.gexplo.2011.06.001 
IUSS Working Group WRB. 2015. World Reference Base for Soil Resources 2014, update 2015. International soil classification system for naming soils and creating legends for soil maps. World Soil Resources Reports 106. FAO, Rome.

Kabala, C. and Singh, B. R. 2001. Fractionation and mobility of copper, lead, and zinc in soil profiles in the vicinity of a copper smelter. Journal of Environmental Quality 30:485492. https://doi.org/10.2134/jeq2001.302485x

Kabata-Pendias, A. 2010. Trace Elements in Soils and Plants. 4th ed. CRC Press, Boca Raton, USA.

Kabata-Pendias, A. and Pendias, H. 1985. Trace elements in soils and plants. CRC Press, Boca Raton. 315pp.

Kachinskii, N. A. 1958. Particle-size and microaggregate composition of soil and methods of its study. AN SSSR, Moscow.

Karpukhin, A.l. and Bushuev, N. N. 2007. Distribution of heavy metals by the molecular weight fractions of humic acids in the soils of lion-term field experiments. Eurasian Soil Science 40(3):265-273. https://doi.org/10.1134/ S1064229307030040

Kryshchenko, V. S. and Kuznetsov, R. V. 2003. Clay minerals in soils of the Lower Don and Northern Caucasus regions. Izvestiya Vysshikh Uchebnykh Zavedeniy. Severo-Kavkazskiy Region. Seriya: Estestvennye Nauki 3:86-92.

Kryshchenko, V.S., Zamulina, I. V., Rybyanets, T. V., Kravtsova, N. E., Biryukova, O.A., and Golobuzov, O. M. 2016. Dynamics of the microaggregate composition of chernozem in relation to changes in the content of organic matter. Eurasian Soil Science 49:640-651. https://doi. org/10.1134/S1064229316060041

Mahanta, M. J. and Bhattacharyya, K. G. 2011. Total concentrations, fractionation and mobility of heavy metals in soils of urban area of Guwahati, India. Environmental Monitoring and Assessment 173:221-240. https://doi. org/10.1007/s10661-010-1383-X

Manceau, A., Marcus, M. A., and Tamura, N. 2002. Quantitative speciation of heavy metals in soils and sediments by synchrotron X-ray technique. In: Application of synchrotron radiation in low temperature geochemistry and environmental science. Reviews in mineralogy and geochemistry. Washington, DC. 49:341-428.

Manceau, A., Marcus, M.A., Tamura, N., Proux, O., Geoffroy, N., and Lanson, B. 2004. Natural speciation of Zn at the micrometer scale in a clayey soil using X-ray fluorescence, absorption, and diffraction. Geochimica et Cosmochimica Acta 68:2467-2483. https://doi.org/10.1016/j. gca.2003.11.021

Manucharov, A. S., Kharitonova, G. V., Chernomorchenko, I. I., and Zemlyanukhin, V. N. 2001. Effect of adsorbed zinc and lead cations on the surface properties of minerals and water vapor sorption. Eurasian Soil Science 34:615-620.

Minkina, T. M., Bauer, T. V., Batukaev, A. A., Mandzhieva, S. S., Burachevskaya, M.V., Sushkova, S. N., Varduni, T.V., Sherstnev, A. K., and Kalinichenko, V. P. 2015. Transformation of technogenic Cu and Zn compounds in chernozem. Environmental Engineering and Management Journal 14(2):481-486.

Minkina, T. M., Linnik, V. G., Nevidomskaya, D. G., Bauer, T. V., Mandzhieva, S. S., and Khoroshavin, V. Y. 2018. Forms of $\mathrm{Cu}$ (II), Zn (II), and Pb (II) compounds in technogenically transformed soils adjacent to the Karabashmed copper smelter. Journal of Soils and Sediments 18:2217-2228. https://doi.org/10.1007/s11368-017-1777-2

Minkina, T. M., Motusova, G. V., and Nazarenko, O. G. 2006. Interaction of heavy metals with the organic matter of an ordinary chernozem. Eurasian Soil Science 39:720726. https://doi.org/10.1134/S1064229306070052
Minkina, T. M., Pinskii, D. L., Mandzhieva, S. S., Bauer, T. V. Sushkova, S. N., and Kushnareva, A. V. 2014. Effect of an attendant anion on the balance of cations in the soil-solution system with an ordinary chernozem as an example. Eurasian Soil Science 47:772-780. https://doi. org/10.1134/S1064229314080109

Minkina, T. M., Soldatov, A. V., Nevidomskaya, D. G., Motuzova, G. V., Podkovyrina, Yu. S., and Mandzhieva, S. S. 2016. New approaches to studying heavy metals in soils by X-ray absorption spectroscopy (XANES) and extractive fractionation. Geochemistry International 54:197-204. https://doi.org/10.1134/S001670291512006X

Mohamed, I., Ahamadou, B., Li, M., Gong, C.X., Cai, P., Liang, W., and Huang, Q. Y. 2010. Fractionation of copper and cadmium and their binding with soil organic matter in a contaminated soil amended with organic materials. Journal of Soils and Sediments 10:973-982. https://doi. org/10.1007/s11368-010-0199-1

Motuzova, G. and Makarychev, I. 2014. Heavy metal pollution as a factor of soil acidification. Advances in Environmental Research 181-187.

Motuzova, G.V. and Bezuglova, O.S. 2007. Ekologicheskii monitoring pochv [Ecological Monitoring of Soils], Moscow: Akademicheskii proekt. 237 pp.

Motuzova, G.V., Makarychev, I.P., Dergham, H. M., Stepanov, A. A., and Barsova, N. U. 2012. Soil organic matter and their interactions with metals: processes, factors, ecological significance. Nova Science Publishers, New York. $136 \mathrm{pp}$.

Nevidomskaya, D. G., Minkina, T.M., Soldatov, A.V., Shuvaeva, V. A., Zubavichus, Y. V., and Podkovyrina, Yu.S. 2016. Comprehensive study of $\mathrm{Pb}$ (II) speciation in soil by X-ray absorption spectroscopy (XANES and EXAFS) and sequential fractionation. Journal of Soils and Sediments 16:1183-1192. https://doi.org/10.1007/s11368015-1198-Z

Ok, Y.S., Usman, A.R.A., Lee, S.S., El-Azeem, S. A. M. A., Choi, B., Hashimoto, Y., and Yang, J. E. 2011. Effects of rapeseed residue on lead and cadmium availability and uptake by rice plants in heavy metal contaminated paddy soil. Chemosphere 85:677-682. https://doi.org/10.1016/j. chemosphere.2011.06.073

Onyatta, J.O. and Huang, P. M. 1999. Chemical speciation and bioavailability index of cadmium for selected tropical soils in Kenya. Geoderma 91:87-101. https://doi. org/10.1016/S0016-7061(99)00002-6

Perelomov, L. V., Pinskiy, D. L., and Violante, A. 2011. Effect of organic acids on the adsorption of copper, lead, and zinc by goethite. Eurasian Soil Science 44:26-33. https://doi. org/10.1134/S1064229311010091

Phuengprasop, T., Sittiwong, J., and Unob, F. 2011. Removal of heavy metal ions by iron oxide coated sewage sludge. Journal of Hazardous Materials 186(1):502-507. https:// doi.org/10.1016/j.jhazmat.2010.11.065

Pinskiy, D. L. 1996. Selectivity coefficients and values of maximal adsorption of $\mathrm{Cd}^{2+}$ and $\mathrm{Pb}^{2+}$ by soils. Eurasian Soil Science 28(6):42-53.

Pinskiy, D. L. and Fiala, K. 1985. Significance of ion exchange and formation of difficultly soluble compounds in the adsorption of $\mathrm{Cu}^{++}$and $\mathrm{Pb}^{++}$on soils. Eurasian Soil Science 17(6):28-37.

Pinsky, D. L. and Minkina, T. M. 2013. Regularities of $\mathrm{Cu}, \mathrm{Pb}$ and $\mathrm{Zn}$ adsorption by chernozems of the South of Russia. Eurasian Journal of Soil Science 2:59-68.

Ponizovskii, A. A. and Mironenko, E. V. 2001. Mechanisms of lead(II) sorption in soils. Eurasian Soil Science 34:371-381.

Ponizovskii, A.A., Studenikina, T.A., and Mironenko, E. V. 1999. Adsorption of copper(II) ions by soil as influenced 
by organic components of soil solutions. Eurasian Soil Science 32:766-775.

Ramos, L., Hernandez, L. M., and Gonzalez, M.J. 1994. Sequential fraction of copper, lead, Raton, USA.

Rodríguez-Oroz, D., Lasheras, E., Aldabe, J., Elustondo, D., Santamaría, J. M., and Garrigó, J. 2012. Heavy metals mobility in experimental disturbed and undisturbed acid soil columns in Spanish Pyrenees. Environmental Engineering and Management Journal 11:1149-1158.

Salati, S., Quadri, G., Tambone, F., and Adani F. 2010. Fresh organic matter of municipal solid waste enhances phytoextraction of heavy metals from contaminated soil. Environmental Pollution 158:1899-1906. https://doi. org/10.1016/j.envpol.2009.10.039

Santillan-Medrano, J. and Jurinak, J. J. 1975. The chemistry of lead and cadmium in soil solid phase formation. Soil Science Society of America, Proceedings 39(5):851-856. https:// doi.org/10.2136/sssaj1975.03615995003900050020x

Scheinost, A. C., Kretzchmar, R. S., and Pfister, S. 2002. Combining selective sequential extractions, $X$-ray adsorption spectroscopy, and principal component analysis for quantitative zinc speciation in soil. Environmental Science and Technology 36:5021-5028. https://doi.org/10.1021/es025669f

Smagin, A. V., Manucharov, A. S., Sadovnikova, N. B., Kharitonova, G. V., and Kostarev, I. A. 2004. The effect of exchangeable cations on the thermodynamic state of water in clay minerals. Eurasian Soil Science 37:473-479.

Sokolova, T. A. 1985. Zakonomernosti profil'nogo raspredeleniya vysokodispersnykh mineralov $v$ razlichnykh tipakh pochv [Profile distributions of finely dispersed minerals in different soil types]. Moscow State University, Moscow. 86pp.

Strawn, D. G. and Baker, L. L. 2008. Speciation of Cu in a contaminated agricultural soil measured by XAFS, M-XAFS, and M-XRF. Environmental Science and Technology 42:3742. https://doi.org/10.1021/es071605z

Tessier, A., Campbell, P. G. C., and Bisson, M. 1979. Sequential extraction procedure for the speciation of particulate trace metals. Analytical chemistry 51(7):844-850. https:// doi.org/10.1021/ac50043a017
Titova, N. A., Travnikova, L. S., and Shaymukhametov, M. S. 1996b. Development of research on the interaction of organic and mineral components of soils. Eurasian Soil Science 28(9):151-161.

Titova, N. A., Travnikova, L. S., Kakhnovich, Z. N., Sorokin, S. E., Schulz, E., and Körschens, M. 1996a. Heavy metal content in various particle-size and density fractions of soils. Eurasian Soil Science 29(7):820-830.

Trofimenko, K. I. and Kizyakov, Yu. E. 1967. Organic matter in separate particle-size fractions from the main soil types of Ciscaucasia. Pochvovedenie 2:82-90.

Vadyunina, A.F. and Korchagina, Z. A. 1973. Methods of studying the physical properties of soils and sediments. Vysshaya Shkola, Moscow.

Vega, F. A., Covelo, E. F., and Andrade, M. L. 2006. Competitive adsorption and desorption of heavy metals in minesoils: influence of minesoil characteristics. Journal of Colloid and Interface Science 298:582-592. https://doi. org/10.1016/j.jcis.2006.01.012

Vityazev, V.G., Chizhikova, N.P., and Shevchenko, A. V. 1983. Specific surface area and mineralogy of clay fractions from podzolic soils. Izvestiya Timiryazevskoy Sel'skokhozyaystvennoy Akademii 3:98-104.

Vityazev, V. G., Kaurichev, I. S., and Rabii, A. 1980. Effect of adsorbed cations and anions on the specific surface area of soils. Pochvovedenie 9:34-40.

Vorob'eva, L. A. (ed) 2006. Theory and practice of the chemical analysis of soils. GEOS, Moscow. 400pp.

Wang, Q. Y., Zhou, D. M., and Cang, L. 2009. Microbial and enzyme properties of apple orchard soil as affected by longterm application of copper fungicide. Soil Biology and Biochemistry 41:1504-1509. https://doi.org/10.1016/j. soilbio.2009.04.010

Yin, H., Tan, N., Liu, C., Wang, Ju., Liang, X., Qu, M., Feng, X., Qiu, G., Tan, W., and Liu, F. 2016. The associations of heavy metals with crystalline iron oxides in the polluted soils around the mining areas in Guangdong Province, China. Chemosphere 164:181-189. https://doi. org/10.1016/j.chemosphere.2016.07.018 